\title{
PERANAN LEMBAGA KEUANGAN SYARIAH DALAM MENGIMPLEMENTSIKAN KEUANGAN INKLUSIF (STUDI PADA BMT MARWAH DAN BADAN AMIL ZAKAT NASIONAL (BAZANAS) KABUPATEN KAMPAR)
}

\author{
Mifta Hasda \\ Universitas Islam Negeri Sultan Syarif Kasim Riau \\ miftahd.falah@gmail.com
}

\begin{abstract}
The financial system has a very important role in the growth and stability of a country's economy. Increasing access to financial institutions for the public is required in order to achieve economic growth and a stable financial system. By changing an exclusive financial system into an inclusive financial system, it is hoped that people in the group in the bottom of the pyramid, most of whom are not reached by formal financial access, can use and take advantage of formal financial services. Baitul Mal wat Tamwil (BMT) and the Zakat Institution are inclusive Islamic financial institutions. The research was conducted in Kampar Regency and is a qualitative research. In Kampar District, BMT Marwah and BAZNAS are sharia financial institutions that directly touch the lower class society. The formulation of the research problem is the efforts of BMT Marwah and BAZNAS Kampar District in implementing financial inclusion and what are the obstacles and solutions in implementing financial inclusion. The results of this study are that BMT Marwah provides financial products that are in accordance with the needs of the community, easy requirements, clarity of records and the existence of a ball-pick service that makes it easy for the community and BMT Marwah can directly socialize with customers or prospective customers. In an effort to realize inclusive zakat, BAZNAS provides a service to pick up zakat or muzakki can transfer to a predetermined account. To increase the number of muzakki, BAZNAS has conducted socialization and education on zakat and the formation of UPZ. The obstacle encountered by BMT Marwah is the character of mudharabah customers who are quite difficult to complete mudharabah financing. BAZNAS in running its operations is constrained by limited funds and the quality of amil which is not yet competent in carrying out its duties, because there is no training and regular coaching of amil.
\end{abstract}

Keywords: Financial Inclusion, Inclusive Zakat, Baitul mal wa tamwil (BMT), National Amil Zakat Agency

\begin{abstract}
Abstrak
Sistem keuangan memiliki peran yang sangat penting dalam pertumbuhan dan stabilitas ekonomi suatu negara. Meningkatkan akses pada lembaga keuangan bagi masyarakat diharuskan agar tercapai pertumbuhan ekonomi dan stabilnya sistem keuangan. Dengan mengubah sistem keuangan yang ekslusif menjadi sistem keuangan yang inklusif maka diharapkan masyarakat pada kelompok in the bottom of pyramid yang sebagian besar tidak terjangkau akses keuangan formal dapat menggunakan dan memanfaatkan layanan jasa keuangan formal. Baitul Mal wat Tamwil (BMT) dan Lembaga Zakat merupakan lembaga keuangan syariah yang bersifat inklusif. Penelitian dilakukan di Kabupaten Kampar dan merupakan penelitian kualitatif. Di Kabupaten Kampar BMT Marwah dan BAZNAS merupakan lembaga keuangan syariah yang langsung menyentuh masyarakat kalangan bawah. Rumusan masalah penelitian ini adalah upaya BMT Marwah dan BAZNAS Kabupaten Kampar dalam mengimplementasikan keuangan inklusif serta apa saja hambatan dan solusi dalam mengimplementasikan keuangan inklusif. Adapun hasil dari penelitian ini adalah BMT Marwah memberikan produk keuangan yang sesuai dengan kebutuhan masyarakat, pesryaratan
\end{abstract}


yang mudah, kejelasan pencatatan dan adanya pelayanan jemput bola memberikan kemudahan bagi masyarkat dan BMT Marwah dapat langsung bersosialisasi dengan nasabah ataupun calon nasabah. Dalam upayanya mewujudkan zakat inklusif BAZNAS memberikan pelayanan jemput zakat atau muzakki dapat transfer ke rekening yang telah ditentukan. Untuk meningkatkan jumlah muzakki BAZNAS melakukan sosialisasi dan edukasi zakat serta pembentukan UPZ. Hambatan yang ditemui BMT Marwah adalah karakter nasabah mudharabah yang cukup sulit untuk menyelesaikan pembiayaan mudharabah. BAZNAS dalam menjalakan operasional terkendala dengan dana yang terbatas serta kualitas amil yang belum cakap dalam melaksanakan tugasnya, dikarenakan belum ada pelatihan dan pembinaan amil secara berkala.

Kata Kunci: Inklusi Keuangan, Zakat Inklusif, Baitul Mal wa Tamwil (BMT), Badan Amil Zakat Nasional

\section{PENDAHULUAN}

Kemiskinan dan tidak merata distribusi pendapatan merupakan permasalahan yang dihadapi banyak Negara, termasuk Indonesia. Pembangunan terus dilakukan pemerintah sebagai upaya agar masyarakat memiliki kesempatan yang sama untuk mendapatkan kehidupan yang sejahtera. Akan tetapi hingga saat ini, pembangunan tidak dapat dinikmati oleh seluruh lapisan masyarakat. Masyarakat menengah ke atas mendapat banyak keuntungan dari pembangunan, sedangkan masyarakat dari kalangan bawah belum bisa memanfaatkannya.

Kesenjangan merupakan salah satu persoalan dalam paradigma pembangunan ekonomi di berbagai Negara berkembang. Munculnya kesenjangan ekonomi akan menimbulkan banyak masalah lain yang bermunculan, seperti penduduk miskin bertambah, pengangguran meningkat, tingkat kejahatan meningkat, kualitas pendidikan menurun, kemampuan daya beli masyarakat yang menurun. (Nurul Huda, 2015, hal. 10)

Berbagai studi menunjukkan bahwa sistem keuangan memainkan peran vital dalam mendorong pertumbuhan ekonomi. Perkembangan sistem keuangan memengaruhi tingkat tabungan, investasi, inovasi, teknologi dan pertumbuhan ekonomi jangka panjang di suatu Negara, bahkan perkembangan sistem keuangan mampu memprediksi perkembangan ekonomi ke depan. Umumnya Negara - Negara yang menjadi pemimpin perekonomian dunia adalah Negara - Negara yang berhasil mengembangkan sistem keuangan yang relative lebih maju dan berfungsi dengan baik. (Soemitra, 2017, hal. 16)

Industri keuangan memainkan peran yang penting dalam mendorong pertumbuhan ekonomi, pemerataan pendapatan, pengetasan kemiskinan dan 
pencapaian stabilitas sistem keuangan melalui pelaksanaan fungsi intermediasi. Perekonomian yang tumbuh berkelanjutan membutuhkan sistem keuangan yang mampu menyalurkan dana secara efisien dari masyarakat penabung (surplus unit) ke masyarakat yang memiliki peluang - peluang investasi produktif (deficit unit). Peran vital sistem keuangan tersebut muncul karena para pelaku ekonomi tersebut selalu dihadapkan kepada tingginya biaya informasi dan biaya transaksi keuangan. Meunculnya dua jenis biaya tersebut mengakibatkan transaksi langsung antara pihak pemilik dana dan pihak yang membutuhkan dana tidak dapat berjalan secara optimal. (Setiawan, 2018, hal. 23)

Survey bank dunia pada tahun 2010 menunjukkan hanya 49\% rumah tangga Indonesia yang memiliki akses terhadap lembaga keuangan formal. Hal serupa ditemukan bank Indonesia dalam survey neraca rumah tangga tahun 2011 yang menunjukkan bahwa persentase rumah tangga yang menabung di lembaga keuangan formal dan non lembaga keuangan sebesar $48 \%$. Rendahnya akses ini disebabkan karena tingkat pendapatan yang rendah, tata operasional bank rumit, kurangnya edukasi keuangan dan perbankan, biaya administrasi bank yang tinggi serta jauhnya lokasi bank dari tempat tinggal mereka. Untuk itu, muncul pemikiran untuk menerapkan strategi keuangan inklusif untuk mendorong kgiatan ekonomi kelompok masyarakat yang belum menikmati layanan keungan, sehingga mendorong pemerataan pendapatan dan pengentasan kemiskinan. (Departemen Pengembangan Akses Keuangan dan UMKN, 2014, hal. 4) Proses eksklusif keuangan membuat masyarakat miskin tidak dapat mengakses benefit dari sektor keuangan dan memberikan kerugian kepada masyarakat untuk mendapat akses terhadap sistem keuangan karena kurang akses, jaminan, riwayat kredit dan jaringan. (Iskandar, 2017, hal. 103)

Strategi nasional keuangan inklusif mendefinisikan keuangan inklusif sebagai kondisi ketika setiap anggota masyarakat mempunyai akses teradap berbagai layanan keuangan formal yang berkualitas secara tepat waktu, lancar dan aman dengan biaya yang terjangkau sesuai dengan kebutuhan dan kemampuan dalam rangka meningkatkan kesejahteraan masyarakat. (Setiawan, 2018, hal. 11)

Untuk menerapkan keuangan yang inklusif tidak hanya menjadi tugas dari Bank Indonesia, namun juga regulator, kementrian dan lembaga keuangan lainnya dalam upaya pelayanan keuangan kepada masyarakat luas. Melalui Strategi Nasional 
Keungan Inklusif diharapkan kolaborasi antara lembaga pemerintah dan pemangku kepentingan tercipta secara baik dan terstruktur.

Indonesia merupakan Negara yang melaksanakan dual system dalam melaksanakan system keuangan, yaitu konvensional dan syariah. Dengan mayoritas jumlah penduduk beragama Islam memberikan kesempatan yang luas bagi lembaga keuangan syariah untuk berkembang. Lembaga keuangan Syariah yang dalam kegiatan usaha berjalan sesuai dengan prinsip syariah berlandaskan nilai - nilai keadilan, kemanfaatan, keseimbangan dan keuniversalan (rahmatan lil 'alamin). Membuat keseoakatan bersama antara lembaga keuangan dan nasabah dalam pembagian hasil dan margin keuntungan mencerminkan nilai keadilan. Lembaga keuangan syariah berkintribusi dalam pengembangan ekonomi secara nasional mewujudkan nilai kemanfaatan.Memposisikan nasabah sebagai mitra untuk berbagi keuntungan dan resiko secara seimbang menunjukkan keseimbangan. prinsip islam sebagai agama yang rahmatan lil alamin tidak membedakan golongsn masyarakat baik dari agama, suku dan ras menunjukkan nilai universal dari lembaga keuangan syariah. (Soemitra, 2017, hal. 33)

Terdapat kesamaan antara keungan inklusif dengan prinsip yang dianut oleh lembaga keuangan syariah yaitu mewujudkan keadilan. Artinya tidak membeda bedakan. melalui produk dan jasa yang ada pada sistem keuangan syariah menjadi jembatan bagi pihak yang membutuhkan dengan pihak yang memiliki kelebihan dana untuk tetap bertransaksi berdasarkan prinsip - prinsip syariah. (Soemitra, 2017, hal. 17)

Di Indonesia, keberadaan BMT (Baytul Maal Wat Tamwil) dapat dianggap sebagai contoh inklusi keuangan syariah. BMT adalah lembaga keuangan mikro syariah yang berperan dalam membuka akses kepada kelompok masyarakat yang selama ini belum terlayani oleh lembaga keuangan. Demikian pula dengan keberadaan BAZNAS dan LAZ (Lembaga Amil Zakat) yang menyediakan sumber keuangan bagi kelompok miskin pada lapisan terbawah masyarakat yang selama ini belum terakses oleh lembaga keuangan yang ada. (Arsyianti, 2017, hal. 299)

Dengan berdirinya BMT akan memberikan kemudahan pelayanan jasa semi perbankan, terutama bagi pengusaha atau pedagang golongan ekonomi lemah sehingga akan mampu menggali potensi, meningkatkan produktivitas, meningkatkan pendapatan serta mengembangkan perekonomian pedesaan. Dengan demikian keberadaan BMT diharapkan mampu mempunyai efek yang sangat kuat dalam menjalankan misinya dan 
dapat mengurangi ketergantungan pengusaha kecil dari lembaga keuangan informal yang bunganya relative terlalu tinggi. Pemberian pembiayaan sedapat mungkin dapat memandirikan ekonomi pengusaha kecil. (Sholahuddin, 2014, hal. 142)

Umat Islam memiliki potensi sumber daya manusia yang banyak, dari para intelektual dan ulama serta memiliki ekonomi yang berlimpah. untuk mendapatkan hasil yang maksimal, maka seluruh potensi perlu dikembangkan secara serius diiringi dengan potensi akidah islamiah (tauhid) yang benar. Kemudian untuk mengurangi kesulitan ekonomi dan kemungkaran diperlukan kemandirian, diperlukannya meningkatnya semangat beragama dan persaudaraan islamiah di tengah - tengah umat untuk dilakukaan secara bersamaan. Penanggulangan kemiskinan dapat dilakukan dengan cara meningkatkan pengumpulan dan pendayagunaan zakat, infak serta sedekah merupakan salah satu ajaran dalam Islam yang perlu dilakukan secara serius. (Sholahuddin, 2014, hal. 262)

Zakat bukanlah semata mata urusan yang bersifat karitatif (kedermawanan), tetapi juga otoritatif (perlu ada kekuatan memaksa). zakat memiliki posisi dan kedudukan yang penting untuk meningkatkan kesejahteraan, menanggulangi kemiskinan serta meningkatkan ekonomi masyarakat, sehingga diperlukannya pengelolaan dalam pengumpulan dan penyaluran dilakukakan secara amanah, transparan dan profesional. (Kamil, 2016, hal. 274)

Kabupaten Kampar merupakan salah satu kabupaten di Provinsi Riau dengan jumlah penduduk 812.702 jiwa (Badan Pusat Statistik Kabupaten Kampar) dan penduduk beragama Islam berjumlah 640.465 atau 92,67\%. (Badan Pusat Statistik Kabupaten Kampar) Adanya pelarangan transaksi yang mengandung unsur riba dalam Islam tentunya membuat masyarakat beragama Islam memiliki kebutuhan untuk bisa mengakses dan memanfaatkan jasa keuangan syariah. BMT Marwah salah satu lembaga mikro syariah yang berada di Kabupaten Kampar dan BAZNAS Kabupaten Kampar sebagai lembaga pengelola zakat, yang diharapkan mampu menjadi lembaga yang dapat menyentuh masyarakat yang belum tersentuh akses lembaga perbankan dalam memunihi kebutuhannya untuk memanfaatkan jasa lembaga keuangan.

Menjadi lembaga keuangan syariah yang inklusif sebuah keharusannya bagi BMT Marwah. Memiliki 4 kantor cabang yang tersebar di Kabupaten Kampar dan BAZNAS Kabupaten Kampar yang setiap tahunnya jumlah penerimaan zakat mengalami peningkatan. Artinya jumlah masyarakat yang mendapat akses keuangan 
dari lembaga keuangan syariah ini akan meningkat. Akan tetapi masih ada masyarakat sekitar pedagang kecil memilih untuk mendapatkan tambahan modal atau menyimpan kelebihan dana secara individu ataupun lembaga keuangan konvensional. Ditambah lagi dengan banyaknya penawaran pinjaman dana degan cepat dan mudah yang ditawarkan melalui selebaran ataupun pesan singkat langusng ke handphone.

Begitu juga dengan zakat dimana sebagian besar masyarakat memilih untuk berzakat secara langsung, sehingga zakat hanya bersifat konsumtif. Hal ini disebabkan oleh beberapa faktor, yaitu kebiasaan dari muzakki, kurangnya pemahaman masyarakat tentang zakat, kurang percaya terhadap lembaga zakat dan kantor lembaga zakat yang jauh. Potensi penerimaan yang dana zakat yang cukup besar seharusnya dapat dimanfaat sebagai sumber dana bagi masyarakat yang belum mampu mengakses lembaga keuangan formal sehingga terwujudnya pemerataan distribusi pendapatan dan pengentasan kemiskinan. Melihat fenomena tersebut penulis merasa perlu melakukan penelitian dengan judul Peranan Lembaga Keuangan Syariah Dalam Mengimplementsikan Keuangan Inklusif (Studi Pada BMT Marwah dan Badan Amil Zakat Nasional (BAZANAS) Kabupaten Kampar).

\section{KERANGKA TEORI}

\section{Pengertian Lembaga Keuangan}

Lembaga keuangan (finansial institution) adalah suatu perusahaan yang usahanya bergerak di bidang jasa keuangan. Artinya kegiatan yang dilakukan oleh lembaga ini akan selalu berkaitan dengan bidang keuangan, apakah penghimpunan dana masyarakat dan/atau jasa-jasa keuangan lainnya. (Mardani, 2015, hal. 1) Lembaga keuangan sendiri dibedakan menjadi dua, yaitu lembaga keuangan konvensional dan lembaga keuangan syariah. (Ghofur, 2017, hal. 127).

Menurut SK Menkeu RI No 792 Tahun 1990 Lembaga keuangan menurut SK Menkeu RI No 792 Tahun 1990 adalah semua badan yang kegiatannya bidang keuangan, melakukan penghimpunan dan penyaluran dana kepada masyarakat terutama guna membiayai investasi perusahaan. Meski dalam peraturan tersebut lembaga keuangan diutamakan untuk membiayai investai perusahaan namun tidak berarti membatasi kegiatan pembiayaan lembaga keuangaan. Dalam kenyataannya kegiatan usaha lembaga keuangan bisa diperuntukkan bagi investasi perusahaan, kegiatan konsumsi dan kegiatan distribusi barang dan jasa. 
Lembaga keuangan didefinisikan oleh Kasmir adalah setiap perusahaan yang bergerak di bidang keuangan, menghimpun dana, menyalurkan dana atau kedua duanya. Artinya kegiatan yang dilakukan oleh lembaga keuangan selalu berkaitan dengan bidang keuangan, apakah kegiatannya hanya menghimpun dana atau hanya menyalurkan dana atau menghimpun dan menyalurkan dana. (Soemitra, 2017, hal. 25 26). Jadi lembaga keuangan merupakan setiap perusahaan yang kegiatannya bergerak di bidang keunagn baik itu menghimpun dana, menyalurkan dana dan jasa keuangan lainnya yang dilakukan secara konvensional maupun syariah.

\section{BMT (Baitul Mal wat Tamwil)}

\section{Pengertian BMT}

Kata baitul mal wat tamwil adalah penggabungan dari kata baitul mal dan kata baitut tamwil. Baitul mal adalah lembaga keuangan yang kegiatannya mengelola dana yang bersifat nirlaba (sosial). Sumber dananya diperoleh dari ZISWa (zakat, infak, sedekah dan Wakaf) atau sumber lain yang halal seperti hibah. Selanjutnya, dana tersebut disalurkan kepada mustahiq (yang berhak menerima). Adapun baitut tamwil adalah lembaga keuangan yang kegiatannya adalah menghimpun dan menyalurkan dana masyarakat yang bersifat profit motive. Penghimpunan dananya diperoleh melalui simpanan pihak ketiga dan penyalurannya dilakukan dalam bentuk pembiayaan atau investasi yang dijalankan berdasarkan prinsip syariah.

BMT merupakan lembaga keuangan Islam yang berbeda dengan bank. M. Amin Azis sebagai pelopor BMT di Indonesia menyebutkan padanan kata Baitul Mal Wat Tamwil (BMT) dalam bahasa Arab dengan Balai-usaha Mandiri Terpadu (BMT) dalam bahasa Indonesia. BMT adalah lembaga ekonomi rakyat yang bertujuan untuk memperkuat ekonomi rakyat jelata atau akar rumput yang melembaga menjadi milik masyarakat. (Kamil, 2016, hal. 199).

Jika dilihat dalam kerangka ekonomi Islam, tujuan BMT dapat berperan melakukan hal - hal berikut : 1). Membantu meningkatkan dan mengembangkan potensi umat dalam program pengentasan kemiskinan. 2). Memberikan sumbangan aktif terhadap upaya pemberdayaan dan peningkatan kesejahteraan umat. 3). Menciptakan sumber pembiayan dan penyediaan modal bagi anggota dengan prinsip syariah. 4). Mengembangkan sikap hemat dan mendorong kegiatan gemar menabung. 5). Menumbuhkan usaha - usaha yang produktif dan sekaligus memberikan bimbingan 
dan konusltasi bagi anggota di bidang usahanya. 6). Meningkatkan wawasan dan kesadaran umat tentang sistem dan pola perekonomian Islam. 7). Membantu para pengusaha lemah untuk mendapatkan modal pinjaman. 8). Menjadi lembaga keuangan alternative yang dapat menopang percepatan pertumbuhan ekonomi nasional. (Ridwan, 2013, hal. 38). 9). Melepaskan ketergantungan kepada para rentenir, masyarakat yang masih tergantung dengan rentenir yang disebabkan rentenir mampu memenuhi keinginan masyarakat dalam memenuhi dana dengan segera. BMT harus mampu melayani masyarakat lebih baik, misalnya selalu tersedia dana setiap saat, birokrasi yang sederhana dan lain sebagainya. (Haykal, 2010, hal. 364)

\section{Lembaga Amil Zakat (LAZ) Di Indonesia}

Pemerintah berhak untuk mengatur sistem zakat bagi rakyatnya, dan berkewajiban membagikan hak kepada rakyat yang membutuhkannya. Di Indonesia masalah zakat telah diatur dalam undang - undang zakat no. 38 tahun 1998 dan undang - undang no 23 tahun 2011. (Zulkifli, 2014, hal. 19)

Berdasarkan UU No 23 tahun 2011 lembaga yang bertugas mengelola zakat yaitu Badan Amil Zakat Nasional(BAZNAS) dan Lembaga Amil Zakat (LAZ). Badan Amil Zakat Nasional (BAZNAS) adalah lembaga yang melakukan pengelolaan zakat secara nasional sedangkan Lembaga Amil zakat (LAZ) adalah lembaga yang dibentuk masyarakat yang memiliki tugas membantu pengumpulan, pendistribusian dan pendayagunaan zakat.

Cara pemindahan atau pemerataan kekayaan seperti ini dimaksudkan agar orang kaya tidak merasa zakat yang dikeluarkannya sebagai kebaikan hati, bukan kewajiban dan fakir miskin tidak merasa berhutang budi pada orang kaya karena menerima pembagian zakat. Apabila zakat dipungut oleh negara, keuntungannya diantara lain adalah sebagai berikut: 1). Para wajib zakat lebih displin dalam menunaikan kewajibannya dan fakir-miskin lebih terjamin haknya. 2). Perasaan fakirmiskin lebih dapat dijaga, tidak merasa seperti meminta - minta. 3). Pembagian zakat akan menjadi lebih tertib. 4). Zakat yang diperuntukkan bagi kepentingan umum seperti sabilillah misalnya, da (Haykal, 2010)pat disalurkan dengan baik karena pemerintah lebih mengetahui sasaran pemanfaatannya. (Ali, 2012, hal. 51 - 52). 


\section{Inklusi Keuangan}

Inklusi keungan terdiri dari kata inklusi dan keuangan. secara bahasa inklusi dapat diartikan sebagai memasukkan, sedangkan keuangan secara bahasa diartikan dengan beberapa hal yang berhubungan dengan uang. Apabila kedua kata tersebut digabungkan memiliki arti yang baru, yang berhubungan dengan sebuah rencana global.

Inklusi keuangan dalam pandangan islam merupakan upaya untuk menimgkatkan akses masyarakat terhadap lembaga keuangan agar pendistribusian dan pengelolaan keuangan ditengah - tengah masyarakat sesuai dengan ajaran Islam. Dengan adanya Inklusi keuangan syariah yang dapat dijadikan sarana untuk meningkatkan keterlibatan masyarakat dalam praktik keuangan syariah. (Arsyianti, 2017, hal. 221)

Pada hakikatnya keuangan inklusif adalah seluruh upaya yang bertujuan meniadakan segala bentuk hambatan terhadap akses masyarakat dalam memanfaatkan layanan jasa keuangan dengan biaya yang terjangkau. Belum terdapat defnisi baku mengenai keuangan inklusif. Namun demikian, beberapa institusi mempunyai definisi masing - masing. (Setiawan, 2018, hal. 9).: a) World Bank mendefinisikan keuangan inklusif sebagai proporsi individu dan perusahaan yang menggunakan produk dan jasa keuangan. b). IMF mendefinisikannya sebagai akses dan penggunaan produk keuangan formal.c) Organization for Economic Co-operation and Development (OECD) mendefinisikan keuangan inklusif sebagai "process of promoting affordable, timely and adequate access to a wide range of regulated financial products and services and broadening their use by all segments of society through the implementation of tailored existing and innovative approaches including financial awareness and education with a view to promote financial well-being as well as economic and social inclusion". d).

OJK mendefinisikan inklusi keuangan sebagai ketersediaan akses pada berbagai lembaga, produk dan layanan jasa keuangan sesuai dengan kebutuhan dan kemampuan masyarakat dalam rangka meningkatkan kesejahteraan masyarakat. e). Strategi Nasional Keuangan Inklusif mendefinisikan inklusi keuangan sebagai hak setiap orang untuk memiliki akses dan layanan penuh dari lembaga keuangan secara tepat waktu, nyaman, informatif, dan terjangkau biayanya, dengan penghormatan penuh kepada harkat dan martabatnya. Layanan keuangan tersedia bagi seluruh segmen masyarakat, dengan perhatian khusus kepada orang miskin, orang miskin produktif, pekerja migrant, dan penduduk di daerah terpencil. 


\section{Inklusi Zakat}

Pemerintah menggagas zakat inclusion sebagai suatu program yang dirancang guna memasyarakatkan zakat secara luas sehingga kegiatan berzakat dapat lebih mudah diakses atau dilakukan oleh masyarakat. Selain itu, akan dilakukan sinergi antara program zakat inclusion dengan program literasi dan inklusi keuangan untuk meningkatkan pemerataan pendapatan, pelayanan keuangan bagi kelompok masyarakat yang belum memiliki akses keuangan dan program pengentasan kemiskinan secara nasional berbasis dana zakat. (Setiawan, 2018, hal. 22)

Perlunya pengoptimalan pengelolaan zakat penghasilan dan zakat perusahaan dalam rangka pemberdayaan perekonomian umat, dapat melalui pemanfaatan teknologi baik untuk pengumpulan zakat, penyaluran zakat, dan edukasi zakat kepada masyarakat. Berdasarkan data BAZNAS Tahun 2018, zakat penghasilan di Indonesia berpotensi mencapai $\mathrm{Rp}$ 175,97 Triliun namun hanya terkumpul sejumlah $\mathrm{Rp}$ 2,79 triliun. Adapun zakat perusahaan yang berpotensi mencapai Rp 248,5 triliun hanya terkumpul sejumlah Rp 307 miliar. Adapun potensi zakat untuk Tahun 2019 mencapai Rp 235,156 triliun. (Putri J. L., 2018, hal. 4).

Peluncuran gagasan inklusi zakat dilakukakn oleh Presiden Joko Widodo, bersama BAZNAS dan OJK pada tanggal 14 Juni 2017 di Istana Negara. Gagasan zakat inklusi adalah sebuah upaya mengajak sebanyak mungkin lapisan masyarakat untuk ikut dalam kampanye zakat dan menjadi agen zakat bagi masyarakat di semua lapisan. Salah satu langkah yang ditempuh untuk mendukung hal itu adalah dengan memulai program penghimpunan zakat melalui ratusan ribu agen Layanan Keuangan Tanpa Kantor dalam Rangka Keuangan Inklusif (Laku Pandai). (Putri, 2018).

\section{METODE PENELITIAN}

Jenis Penelitian ini adalah penelitian lapangan (field research) adalah penelitian yang langsung dilakukan dilapangan atau kepada responden. (Sangadji, 2010, hal. 28) Metode penelitiannya adalah metode kualitatif yaitu suatu metode penelitian yang temuan - temuan penelitian tidak diperoleh melalui prosedur statistic atau bentuk hitungan lainnya. (Anwar S. , 1999, hal. 8). Metode penelitian ini dengan kualitatif dengan pendekatan komparatif dengan menggambarkan implementasi keuangan inklusif di lembaga keuangan syariah yaitu BMT Marwah dan BAZNAS Kab. Kampar. 
Dalam penelitian ini, peneliti menggunakan informan penelitian utama (Key Informan). Yang dimaksud Informan penelitian utama (Key Informan) adalah orang yang paling tahu banyak informasi mengenai objek yang sedang diteliti atau data yang dikumpulkan oleh peneliti langsung dari sumber pertama. (Bungin, 2008, hal. 77) Untuk memilih informan kunci lebih tepat digunakan secara sengaja (purposive sampling). (Bungin, 2008, hal. 53)

Adapun key penelitian ini adalah pimpinan BMT Marwah dan pengurus Badan Amil Zakat Nasional (BAZNAS) Kabupaten Kampar. Kemudian selain key informan dalam penilitian ini, peneliti akan menyebarkan kepada nasabah BMT Marwah serta muzakki dan mustahik BAZNAS Kabupaten Kampar untuk melakukan triangulasi.

Analisis data merupakan upaya mencari dan menata secara sistematis catatan hasil observasi, wawancara dan lainnya untuk meningkatkan pemahaman peneliti tentang kasus yang diteliti dan menyajikannya sebagai temuan bagi yang lain, sedangkan untuk meningkatkan pemahaman tersebut analisis perlu dilanjutkan dengan berupaya mencari makna (meaning). (Muhadjir, 1998, hal. 124) Pada proses analisis data kualitatif terdapat 3 (tiga tahapan), yaitu reduksi data (data reduction), penyajian data (data display) dan pengambilan kesimpulan/verifikasi.

\section{PEMBAHASAN}

\section{Upaya BMT Marwah Dalam Mengimplementasikan Keuangan Inklusif}

BMT Marwah berdiri pada tahun 2006, didirikan sebagai langkah awal untuk menuju Ekonomi Syariah dan mewujudkan masyarakat madani. Seiring dengan perkembangannya kini BMT Marwah memiliki empat kantor, dimana satu kantor pusat, tiga kantor cabang yang tersebar di Kabupaten Kampar dan Pekanbaru. Modal awal dalam pendirian BMT Marwah sebesar 1.000.000.000. Adapun jumlah anggota pada awal pendirian sebanyak 35 orang dan sekarang terdapat 2.646 anggota.

Visi BMT Marwah adalah menjadi lembaga yang sehat, peduli dan terpecaya yang bercirikan masyarakat produktif dengan SDI yang professional menuju kesejahteraan bersama dunia dan akhirat. Sedangkan Misi BMT Marwah yaitu : 1). Mengedepankan akhlakulkarimah sesuai dengan prinsip Islam. 2). Meningkatkan efektifitas dan efesiensi financial. 3). Menjalin silaturahmi dan menjaga amanah. 4). Meningkatkan produktivitas masyarakat. 5). Mengutamakan kedisiplinan, kejujuran dan meningkatkan profesionalitas. 
Untuk menjadi anggota BMT Marwah melengkapi syarat sebagai berikut : a). Foto copy KTP, b). Foto copy KK, c). Isi formulir, d). Iuran simpanan 10.000/anggota(Wawancara Ka. Operasional BMT Marwah, Shapyani 06 Februari 2020). Adapun produk - produk simpanan yang ada di BMT Marwah adalah sebagai berikut:

\section{Produk - Produk Simpanan}

\section{Simpanan Marwah}

Simpanan marwah adalah simpanan untuk perorangan/lembaga guna menumbuhkan budaya menabung masyarakat dengan keunggulan, yaitu: bebasa biaya bulanan, bisa antar jemput (jemputan ke rumah - rumah/instansi), dan setoran awal Rp. 50.000,- dan saldo minimal Rp. 20.000,--

\section{Simpanan Pendidikan}

Merupakan simpanan pendidikan untuk anak sekolah, PAUD, TK, SD, SMP, SMA/SMK guna menumbuhkan budaya menabung anak - anak mulai dari bangku sekolah dengan persyaratan yang mudah dengan keungulan: bebas biaya administrasi bulanan, bisa antar jemput (jemputan ke rumah - rumah siswa/instansi), setoran awal Rp. 10.000,- dan saldo minimal Rp. 10.000,

\section{Simpanan Qurban}

Simpanan Qurban merupakan simpanan yang dikhususkan untuk keperluan Qurban yang pengambilannya menjelang Hari Raya Qurban (Idul Adha), syarat yang mudah dan cepat dengan keuanggulan, yaitu: bebas biaya administrasi bulanan, layanan antar jemput (dalam suatu majelis ta'lim dan perorangan), dan setoran awal Rp. 50.000,- dan saldo minimal Rp. 20.000,--

\section{Simpanan Haromain}

Simpanan haromain merupakan simpanan untuk umroh, dengan simpanan haromain rencana umroh akan lebih terjaga, dengan keunggulan, yaitu: bebas biaya administrasi bulanan, layanan antar jemput ke rumah anggota (dalam suatu majelis ta'lim dan perorangan), setoran awal Rp. 100.000,- dan saldo minimal Rp. 50.000,-. 


\section{Simpanan Berjangka (Deposito Syariah)}

Merupakan pilihan investasi dengan akad mudharabah dengan jangka waktu 1, 3, 6, 12 dan 24 bulan yang diperuntukkan bagi anggota/calon anggota yang ingin berinvestasi secara halal sesuai dengan syari'ah. Dana akan diinvestasikan secara optimal untuk membiayai berbagai macam usaha produktif yang berguna bagi kepentingan ummat.

Perbandingan jangka waktu dan tingkat bagi hasil untuk simpanan berjangka (deposito syariah) sebagai berikut :

Tabel. 1 Bagi hasil simpanan berjangka

\begin{tabular}{ccc}
\hline JANGKA WAKTU & BMT & ANGGOTA/CALON ANGGOTA \\
1 bulan & $65 \%$ & $35 \%$ \\
3 bulan & $60 \%$ & $40 \%$ \\
6 bulan & $55 \%$ & $45 \%$ \\
12 bulan & $50 \%$ & $50 \%$ \\
24 bulan & $40 \%$ & $40 \%$ \\
\hline
\end{tabular}

\section{Produk - Produk Pembiayaan}

\section{Pembiayaan Murabahah}

Merupakan akad jual beli barang antara mitra BMT dengan menyatakan harga beli/harga pokok yang ditambah keuntungan margin yang disepakati oleh kedua belah pihak. BMT membelikan barang yang dibutuhkan mitra atau BMT memberikan kuasa kepada mitra untuk membeli barang sesuai kebutuhan mitra atas nama BMT. Lalu barang tersebut dijual kepada mitra dengan harga pokok ditambah dengan keuntungan yang diketahui dan disepakati bersama dengan pengembalian secara angsuran. Adapun ketentuan pembiayaan: i) Jujur dan amanah, ii) Mempunyai usaha yang jelas (tidak usaha yang melanggar syariat islam), iii) Mengisi formulir permohonan pembiayaan yang telah disediakan BMT, iv) Menyerahkan foto copy KTP, KK, Surat Nikah dan fotocopy jaminan (2 Lembar), v) Bersedia di survey usaha usaha dan jaminan, vi) Bersedia mematuhi ketentuan - ketentuan yang berlaku bagi anggota/calon anggota BMT.

Sebelumnya BMT Marwah memiliki produk pembiayaan mudharabah akan tetapi produk ini sudah ditiadakan sejak tahun 2017. Hal ini disebabkan kesadaran anggota pembiayaan yang rendah untuk mengembangkan usaha, sedangkan BMT Marwah sebagai lembaga keuangan syariah tidak bisa mengambil agunan. Bahkan 
hingga saat ini BMT masih melakukan pendekatan kepada anggota pembiayaan untuk dapat mengasur pembiayaan mereka. (Wawancara Kepala Kantor Cabang Utama Dodi Saputra,06 Februari 2020)

\section{Produk layanan jasa}

Selain produk simpanan dan pembiayan, BMT Marwah memiliki produk layanan jasa yang memudahkan anggota dalam bertransaksi secara online antara lain: transfer secara online langsung sampai (real time) ke bank tujuan, pembayaran tagihan telepon (TELKOM) dan operator lain, pembayaran angsuran (FIF, ACC, ADIRA FINANCE), pembayaran tagihan rekening listrik/PLN, penarikan tunai ATM mini, dan transaksi online lainnya.

Untuk melakukan transaksi ini dapat dilakukan oleh anggota dengan langsung mendatangi kantor atau bisa mengguna aplikasi payBMT. Aplikasi payBMT adalah sebuah aplikasi dari BMT untuk dimana anggota BMT bia mengisi saldo pulsa, paket internet, token listrik, membayar tagihan listrik prabayar, PDAM, yang bisa dilakukan dari hp sendiri. Artinya dengan apliksi ini dapat mempermudah transaksi anggota dan menghemat waktu. (Wawancara Kepala Kantor Cabang Utama Dodi Saputra,06 Februari 2020

Dalam memasarkan produknya BMT melakukan sosialisasi langsung ke masyarakat seperti ke jamaah masjid, sekolah - sekolah. Memberikan kemudahan bagi calon anggota yang akan bergabung dengan persyataan yang mudah dan murah. Jika anggota tidak bisa ke kantor langsung maka BMT memberikan pelayanan jemput bola ke rumah rumah, ke sekolah, maupun ke tempat pengajian. (Wawancara Kepala Kantor Cabang Utama Dodi Saputra,06 Februari 2020).

\section{Implementasi Keuangan Inklusif di BMT Marwah}

Implementasi keuangan inklusif di BMT Marwah dapat dilihat pada tabel berikut :

Tabel. 2 Implementasi keuangan Inklusif di BMT Marwah

\begin{tabular}{cl}
\hline Indikator & \multicolumn{3}{c}{ Implementasi di BMT Marwah } \\
Akses & Letak lokasi mudah untuk dijangkau masyarakat karena \\
& terletak di pertokoan pasar Danau Bingkuang, adanya \\
& layanan jemput bola sehingga bagi anggota yang tidak \\
& bisa langsung ke kantor bisa memanfaatkan layanan \\
& jemput bola tanpa menggangu aktivitas lainnya, \\
& kemudian anggota juga dapat melakukan beberapa \\
\hline
\end{tabular}




\begin{tabular}{|c|c|}
\hline & $\begin{array}{l}\text { transaksi keuangan melalui aplikasi payBMT. Untuk } \\
\text { bergabung menjadi anggota persyaratan cukup mudah. } \\
\text { Begitu pula persyaratan untuk mengajukan pembiayaan } \\
\text { dianggap cukup mudah bagi anggota. }\end{array}$ \\
\hline Penggunaan & $\begin{array}{l}\text { Anggota dapat memilih dan menggunakan produk sesuai } \\
\text { dengan kebutuhan. Untuk menggunakan produk dan jasa } \\
\text { bisa dilakukan setiap hari kerja, langsung ke kantor, } \\
\text { memanfaatkan layanan jemput bola ataupun melalui } \\
\text { aplikasi payBMT }\end{array}$ \\
\hline Kualitas & $\begin{array}{l}\text { Untuk saat ini produk simpanan di BMT Marwah sudah } \\
\text { sesuai dengan kebutuhan masyarakat. Layanan jemput } \\
\text { bola dan aplikasi payBMT mempermudah anggota untuk } \\
\text { melakukan transaksi keuangan. Akan tetapi } \\
\text { diperlukannya sebuah aturan dan pengawasan agar } \\
\text { produk pembiayaan mudharabah dapat kembali } \\
\text { dijalankan. Sehingga anggota dapat memanfaatkan } \\
\text { produk pembiayaan mudharabah tidak hanya produk } \\
\text { pembiayaan murabahah. }\end{array}$ \\
\hline
\end{tabular}

Dalam penelitaian ini, penulis mewawancara beberapa anggota BMT Marwah yang telah bergabung diatas 2 tahun, diantaranya : 1). Ibuk Tati. Memiliki usaha ponsel bergabung dengan BMT lebih kurang 3 tahun. Manfaat yang ia rasakan kemudahan jika ingin menabung serta dapat menarik uang tabungan jika diperlukan (Wawancara Nasabah BMT Marwah Tati,06 Februari 2020). 2). Ibuk Wati sehari hari berjualan gorengan dan makanan tradisonal di pasar telah menjadi anggota BMT lebih dari 3 tahun. Ia menjadi anggota BMT dengan memanfaatkan jasa simpanan, hanya di BMT yang bisa menerima berapapun uang yang ia tabung, terkadang hanya 10.000 BMT maumenerimanya. Tabungan ini dimanfaatkan ibuk wati untuk biaya sekolah anaknya. Jika pada akhir semester membutuhkan biaya untuk sekolah BMT dapat mencairkan dengan cepat. Apalagi adanya jasa antar jemput semakin mempermudah. (Wawancara Nasabah BMT Marwah Wati, 06 Februari 2020)

\section{Upaya BAZNAS Kab. Kampar Dalam Mengimplementasikan Keuangan Inklusif}

Lembaga pemerintahan nonstruktural yang bersifat mandiri kemudian bertanggung jawab kepada Bupati Kampar dan Badan Amil Zakat Nasional Provinsi Riau yang dapat melakukan pengelolaan zakat di Kabupaten Kampar adalah Badan Amil Zakat Nasional (BAZNAS) Kabupaten Kampar.

Visi BAZNAS Kabupaten Kampar adalah sebagai pusat yang kompeten dan terpercaya dalam melayani muzaki berzakat dengan benar dan mensejahterakan 
mustahik menuju Kampar Berkah. Adapun Misi BAZNAS Kabupaten Kampar yaitu: 1). Mengembangkan kompetensi pengelola zakat sehingga menjadi lembaga pilihan utama umat. 2). Membangun pusat rujukan zakat tingkat kota (Kabupaten Kampar) untuk tata kelola, aspek syariah, inovasi program dan pusat data zakat bagi seluruh pengelola zakat. 3). Mengembangkan kapabilitas pengelolaan zakat berbasis teknologi modern sehingga terwujud pelayanan zakat yang transparan, efektif dan efisien. 4). Menjalankan pengelolaan zakat yang amanah sehingga mendapat kepercayaan dari masyarakat. 4). Memberikan pelayanan bagi muzaki untuk menunaikan zakat dengan benar sesuai syariah. 5). Mengembangkan pelayanan dan program pemberdayaan untuk meningkatkan kesejahteraan mustahik. 6). Mensinergikan seluruh potensi dan kekuatan para pemangku kepentingan zakat untuk memberdayakan umat.

\section{Pengumpulan ZIS BAZNAS Kab.Kampar}

Adapaun upaya yang dilakukan BAZNAS dalam pengumpulan dana zakat yaitu : a). Sosialisasi dan edukasi zakat, b) Pembentukan UPZ, c). Advokasi dan layanan zakat.

Pengumpulan dana zakat di Baznas Kab. Kampar dapat dilakukan melalui transfer ke rekening diantaranya rekening bank riau kepri syariah 820-21-57082, rekening bank mandiri syariah 7051459371 dan bank muamalat 2270006478, sedangkan infak rekening bank mandiri syariah 7051459468. Hal ini dilakukan sebagai salah satu upaya untuk mempermudah muzaki dalam membayarkan kewajiban zakatnya sehingga tidak perlu ke kantor membawa uang dalam jumlah cash, di tambah lagi wilayah kabupaten Kampar yang cukup luas, sehingga yang jauh dari kantor bisa menunaikan zakat dengan lebih mudah. (Wakil Ketua I Bidang pengumpulan, Abazua Anwar, 27 Januari 2020) Seperti Desa Karya Indah di tapung bisanya mereka transfer zakat yang telah terkumpul. Setelah muzakki melakukan transfer ke rekening yang telah ditentukan dapat melakukan konfirmasi kepada staff pengumpulan. (Wawancara, Staff Bidang Pengumpulan, Abu Bakar H, 27 Januari 2020.). Berikut tabel penerimaan zakat, infaq dan sedekah BAZNAS Kabupaten Kampar tahun 2016 - 2019:

Tabel. 3 penerimaan zakat, infaq dan sedekah BAZNAS Kabupaten Kampar tahun 2016 - 2019

\begin{tabular}{cc}
\hline Tahun & ZIS \\
\hline 2016 & Rp. 6.659.891.296 \\
\hline 2017 & Rp. 7.857.994.993 \\
\hline 2018 & Rp. 8.254.294.951 \\
\hline
\end{tabular}




\begin{tabular}{cc}
\hline 2019 & Rp. 10.238 .430 .406 \\
\hline Jumlah & Rp. 33.010.611.646 \\
Sumber: Badan Amil Zakat Nasional(BAZNAS) Kabupaten Kampar
\end{tabular}

\section{Pendistribusian dan Pendayagunaan ZIS BAZNAS Kab. Kampar}

Dalam mendistribusikan dana zakat, Baznas Kab. Kampar menyalurkan dana zakat dalam beberapa program:

\section{KAMPAR MAKMUR}

Penyaluran zakat dilaksanakan untuk tujuan konsumtif, disamping itu juga disalurkan kepada mustahik potensial produktif, yaitu: a). Bantuan usaha ekonomi produktif, b). Pelatihan dan pendampingan UMKM, c). ZCD Bazmart, d). ZCD Home industry, e). ZCD peternakan dan pertanian.

\section{KAMPAR CERDAS}

Program ini merupakan bantuan untuk anak - anak dari keluarga kurang mampu, dalam menjalankan proses pendidikannya. Sehingga dengan adanya program ini, diharapkan dapat meningkatkan kecerdasan anak bangsa, melalui: a). Beasiswa anak berprestasi tingkat SLTP dan SLTA, b).Satu keluarga miskin satu sarjana, c). Bantuan hutang pendidikan, d). Bantuan kuliah keluar negri, e). Bimbingan belajar mustahik

\section{KAMPAR SEHAT}

Program ini merupakan penyaluran dana ZIS kepada mustahiq guna keperluan biaya pengobatan dan atau memberikan bantuan alat kesehatan serta pelayanan antar jemut ambulance gratis bagi du'afa. Bantuan ini merupakan bantuan yang bersifat tanggap darurat dan insidentil, berupa: a). Bantuan insidentil, b). Layanan ambulance, c). Bantuan alat kesehatan, d). Bantuan penderita gizi buruk, e). Bekam masal, f). Khitan masal

\section{KAMPAR TAQWA}

Penyaluran dana zis melalui program ini ditujukan untuk pencerahan mustahik demi terwujudnya peningkatan kualitas mental dan spiritual mustahik, melalui: a). Bantuan guru TPA dan PDTA, b). Bantuan Muallaf, c). Kelas pembinaan muallaf, d).Santunan merbot, e). Kelas pembinaan dai, f).Da'I monitoring dan Advokasi. 


\section{KAMPAR PEDULI}

Program ini merupakan program pendistribusian dana zakat kepada mustahik fakir ( termasuk didalamnya jompo, dengan bantuan Rp. 250.000,- s/d Rp. 300.000,per bulan. Miskin dan gharimin untuk memenuhi kebutuhan hidup serta ibnu sabil (musafir) yang tidak bisa melanjutkan perjalannya karena terkendala biaya. Bantuan ini juga dapat disalurkan kepada korban bencana alam seperti banjir, tanah longsor, kebakaran rumah dan tanggap darurat lainnya, melalui: a). Bantuan fakir miskin konsumtif, b). Bedah rumah, c). Bantuan bencana alam, d). Bantuan jompo, e). Bantuan ibnu sabil

Adapun ketentuan calon mustahik penerima zakat dengan ketentuan sebagai berikut : 1). Mempedomani syarat dan kriteria seperti ketentuan, 2). Belum pernah menerima zakat dari BAZNAS kabupatem Kampar dalam kurun waktu 2 tahun terakhir. 3). Calon mustahik yang diusulkan a,n kepala keluarga berdomisili di wilayah kabupaten Kampar. 4). Karena survey dilakukan hanya sekali maka perlu disiapkan cadangan calon mustahik.

UPZ dari setiap kantor SKPD atau UPZ desa diminta memberikan daftar nama calon mustahik yang sesuai kriteria yang telah ditentukan. Adapun porsi yang diberikan sebelumnya 30\% calon mustahik dari UPZ, untuk sekarang ini 10\% calon mustahik dari dinas selebihnya BAZNAS akan mentukan dan survey sendiri calon mustahik. (Putra, 2020)

Untuk program pendistribusian zakat produktif seperti memberikan pelatihan membuat kue tradisional yang mana satu kelompok terdiri dari 3 anggota, setiap anggota akan mendapatkan peralatan dan bahan untuk memulai usahanya. Selain pelatihan membuat kue, juga ada pelatihan untuk menjahit yang mana satu kelompoknya terdiri dari 3 orang, kemudian asetiap kelompok mendapatkan mesin jahit biasa dan mesin jahit pinggir senilai lebih kurang Rp. 6.000.000. Kemudian ibu ibu pedagang sayur yang ada di pasar biasanya meminjam uang dari rentenir untuk modal usahanya mulai tahun 2019 BAZNAS memberikan modal usaha Rp. 500.000 per orang untuk modal usaha. Kemudian Baznas memiliki program ZCD (Zakat Community Development) BAZMart dan ZCD Peternakan. (Wawancara, Staff Bidang Penditribusian dan Pendayagunaan, Hendri Putra,19 Februari 2020). 


\section{Implementasi Zakat Inklusif di BAZNAS Kab. Kampar}

Zakat inklusif yang merupakan program agar zakat lebih mudah di akses. Inklusi Zakat di BAZNAS Kab. Kampar dari segi akses, penggunaan dan kualitas dapat diuraikan sebagai berikut :

Tabel. 4 Implementasi Zakat Inklusif di BAZNAS Kab. Kampar

\begin{tabular}{cl}
\hline Indikator & Implementasi Zakat Inklusif di BAZNAS Kab. \\
Akses & Kampar \\
& Untuk mengakses wajib zakat (muzaki) bisa ke kantor \\
& yang berada di Komplek Markaz Islami Kab. Kampar, \\
& dikarenakan wilayah Kabupaten Kampar yang luas \\
& BAZNAS Kab. Kampar membentuk UPZ di setiap \\
& kantor dinas/swasta, UPZ masjid, UPZ kecamatan, \\
& adanya layanan jemput zakat atapun wajib zakat bisa \\
& mentransfer ke rekening yang telah ditentukan oleh \\
& BAZNAS Kab. Kampar. Sedangkan bagi penerima \\
& manfaat (mustahik) yang berlokasi dekat dengan \\
& kantor dapat langsung ke kantor sedangkan yang lokasi \\
& jauh BAZNAS menyalurkan langsung ke Kecamatan \\
& ataupun langsung ke rumah - rumah mustahik \\
& Bagi wajib zakat dapat menyalurkan zakatnya melalui \\
& BAZNAS Kab. Kampar ketika nisab dan haul harta \\
& telah terpenuhi. Selanjutnya zakat terkumpul akan di \\
& distribusikan kepada penerima zakat dalam bentuk \\
Perbagai program. Penerima zakat cukup memenuhi & syarat dan kriteria yang ada. Setelah syarat dan kriteria \\
& terpenuhi penerima dapat menggunakan sesuai \\
kebutuhan. & Wajib zakat dapat kemudahan dengan dan \\
& mendapatkan laporan pendistribusian zakat. Program \\
pendistribusian saat sekarang ini cukup memenuhi & kebutuhan penerima zakat baik untuk tujuan konsumtif \\
& maupaun produktif. Akan tetapi masih diperlukan \\
inovasi program yang dibutuhkan mustahik, kemudian & komunikasi dan pengawasan lebih baik oleh BAZNAS \\
kepada wajib zakat maupun penerima zakat.
\end{tabular}

Peneliti juga mewawancara beberapa orang mustahik BAZNAS Kab. Kampar diantaranya : a). Ibuk Nanik, mustahik yang menerima uang Rp. 700.000 dan sembako dari BAZNAS Kab. Kampar. Ia merasa sangat terbantu dengan mendapatkan manfaat dari zakat tersebut. Dengan itu bisa memennuhi kebutuhan pokoknya, terkadang ia harus berhutang untuk memenuhi kebutuhan rumah tangga. (Wawancara, Mustahik BAZNAS Kab. Kampar Nanik 14 Maret 2020), b). Ibuk Eni, juga mustahik yang menerima manfaat sama dengan ibuk Nanik dengan manfaat yang di dapat dari dana 
zakat terbantu dalam memenuhi kebutuhan pokok. (Wawancara, Mustahik BAZNAS Kab. Kampar Nanik 14 Maret 2020), c). Cahya Masitoh, seorang pelajar di pesantren yang mendapatkan manfaat berupa pelatihan tahfiz selama dua bulan di Pekanbaru. Keingingan yang besar untuk menjadi hafiz membuat nya sangat senang dengn mengikuti pelatihan tersebut. Sepulangnya dari pelatihan cahya sudah menghapal 17 juz. (Wawancara, Mustahik BAZNAS Kab. Kampar Cahya Masitoh 14 Maret 2020)

\section{Hambatan dan Solusi dalam Mengimplementasikan Keuangan Inklusi}

Keuangan inklusif merupakan strategi nasional yang berupaya untuk meningkatkan perekonomian, pemerataan pendapatan, pengentasan kemiskinan dan mewujudkan stabilitas keuangan. BMT dan BAZNAS adalah lembaga yang dalam praktinya menerapkan keuangan yang inklusif. Dalam mewujudkan keuangan inklusif tentu terdapat hambatan yang ditemui baik dari BMT Marwah maupun BAZNAS Kab. Kampar.

Dalam wawancara yang peneliti lakukan di BMT Marwah, memberikan layanan jasa keuangan syariah dengan mudah, murah dan aman menjadi keunggulan yang mereka miliki. Terbukti dari anggota merasa sangat terbantu dengan adanya produk simpanan yang murah artinya biaya administrasi yang terjangkau, kemudahan dari system jemput bola yang dilakukan BMT, dan pencatatan yang jelas. Akan tetapi untuk mewujudkan keuangan inklusi dalam hal pembiayaan kepada anggota cukup sulit, seperti banyaknya pembiayan mudharabah yang bermasalah. Dalam menerapkan pembiayaan mudharabah BMT tidak mewajibkan adanya jaminan, jika ada jamianan tidak dapat di sita begitu saja. Sedangkan anggota yang mendapatkan pembiayaan mudharabah kebayakan sulit untuk menyelesaikan pembiayaan dengan berbagai alasan. Karakter masyarakat yang seperti ini membuat pembiayaan ini di hentikan untuk sementara waktu. Kemudian persepsu sebagian masyarakat belum bisa membedakan BMT, lembaga keuangan konvensional, maupun rentenir.

Adapun solusi yang dapat dilakukan BMT perlu menemukan pola pembiayaan mudharabah yang aman, saling menguntungkan bagi BMT dan nasabah pembiayaan. Kemudian perlunya memberikan pengetahuan kepada masyarakat tentang hak dan kewajiban sebagai nasabah pembiayaan mudharabah. Kemudian memanfaatkan teknolgi dalam aktivitas layanan jasa keuangan juga masih perlu ditingkan, karena keuangan inklusif tidak terlepas dari pemanfaatan kemudahan yang diberikan 
teknologi dalam memanfaat layanan jasa keuangan. Kebiasaan dari masyarakat yang menggunakan smartphone sebatas untuk mendapatkan hiburan, perlu adanya sosialisasi tentang pemanfaatan smartphone untuk mendapatkan jasa keuangan.

Dalam penerapan zakat inklusif di BAZNAS Kab. Kampar baik untuk pengumpulan dan pendistribusian zakat non tunai melalui layanan keuangan tanpa kantor belum diterapkan. Kerja sama antara OJK dan BAZNAS tahun 2017 ini belum diterapkan di seluruh Indonesia. Tentunya untuk menerapkan ini BAZNAS menunggu instruksi dari BAZNAS pusat. BAZNAS terus melakukan sosialisasi dan edukasi kepada instansi pemerintahan dan pihak swasta. Dalam upaya memberikan kemudahan bagi muzakki yang ada di Kabupaten Kampar BAZNAS memeliki rekening bank yang dapat dimanfaatkan untuk menyalurkan zakatnya dan layanan jemput zakat. Bagi mustahik calon penerima manfaat zakat tidak dipersulit dengan berbagai persyaratan. BAZNAS berupaya untuk Cara pendistribusian zakat selama ini masih dilakukan secara langsung karena dengan cara ini selain bisa bersilaturahmi, mustahik dapat langsung memanfaat zakat tersebut. sebagaimana tujuan dari keungan inklusif tidak meningkatkan jumlah pembukaan rekening dari masyarakat unbankable melainkan peningkatan kesejahteraan masyarakat. Dalam pelaksaaan tugas kelapangan BAZNAS membutuhkan kendaraan operasional, untuk itu BAZNAS akan membeli kendaraan sepeda motor mengggunakan dana infak. Kemudian kualitas amil yang belum cakap dalam melaksanakan tugasnya, dikarenakan belum ada pelatihan dan pembinaan amil secara berkala. Untuk menunjang kegiatan BAZNAS maka pimpinan berupaya untuk mendapatkan alokasi dana APBD Kabupaten Kampar sesuai dengan mekanisme dan prosedur yang berlaku.

\section{KESIMPULAN}

Upaya BMT dalam mengimplementasikan keuangan inklusif adalah dengan memberikan produk - produk keuangan yang sesuai dengan kebutuhan masyarakat. Pesryaratan yang mudah, kejelasan pencatatan setiap transaksi. Berinteraksi secara langsung dengan masyarakat sebagai upaya untuk mengenalkan produk, meningkat kepercayaan masyarakat sekitar dan pelayanan yang diberikan kepada nasabah atau calon nasabah. Akan tetapi pembiayaan mudharabah diberhentikan untuk sementara dikarenakan karakter masyarakat yang sulit untuk menyelesaikan pembiayaannya. Upaya BAZNAS Kabupaten Kampar dalam mengimplementasikan keuangan inklusif 
dilakukan dengan berbagai cara untuk meningkatkan pengumpulan zakat dengan cara sosialisasi, pembentukan UPZ, advokasi dan pelayanan zakat. Dengan cara ini diharapkan semakin meningkatkan kepercayaan muzaki untuk berzakat di BAZNAS seihingga jumlah zakat yang terkumpul semakin besar dan dapat dimanfaatkan mustahik. Melalui pendistribusian zakat mustahik yang telah mendapatkan manfaat zakat. Bagi yang sebelumnya kesulitan memenuhi kebutuhan pokok terbantu dengan adanya zakat konsumtif, mustahik yang sebelumnya memiliki usaha tetapi terkendal modal untuk mempertahankan dan mengembangkan usaha maka terbantu dengan adanya zakat konsumtif. Berbagai hambatan ditemui dalam upaya mengimplementasikan keuangan inklusif baik oleh BMT maupun BAZNAS, akan tetapi BMT dan BAZNAS mengupayakan berbagai cara untuk mengatasi hambatan tersebut.

\section{DAFTAR PUSTAKA}

Abdul Ghofur, 2017, Pengantar Ekonomi Syariah, Depok : Rajawali Press

Ahmad Hasan Ridwan, 2013, Manajemen Baitul Mal Wa Tamwil, Bandung : CV. Pustaka Setia

Andri Soemitra, 2017, Bank Dan Lembaga Keuangan Syariah, Jakarta : Kencana Azwar Iskandar,Index Of Syariah Financial Inclusion In Indonesia, Bulletin Ekonomi Moneter dan Perbankan. Vol. 20, No 1, Juli 2017,

Booklet Keuangan Inklusif, 2014, Departemen Pengembangan Akses Keuangan dan UMKM: Bank Indonesia

BPS Kabupaten Kampar, https://kamparkab.bps.go.id/indicator/12/40/1/jumlahpenduduk-menurut-kecamatan.html , (diakses pada tanggal 8 Juli 2019)

Burhan Bungin, 2008, Analiis Data Penelitian Kualitatif, Jakarta : Rajawali Pers

Burhan Bungin, 2007, Penelitian Kualitatif, Jakarta: Kencana Prenada Media Group

Etta Mamang Sangadji,2010, Metode Penelitian Pendekatan Praktis Dalam Pennelitian, Yogyakarta : Andi Yogyakrta

http://presidenri.go.id/berita-aktual/peluncuran-gagasan-zakat-inklusi.html, diakses pada tanggal 29 juli 2019 (Putri, 2018)

Irfan Syauqi Beik dan Laily Dwi Arsyianti, 2017, Ekonomi Pembangunan Syariah, Jakarta : Rajawali Press 
Juwita Lukytasari Putri, Indonesia Shari'a Economic Festival (ISEF) 2018, Buletin SNKI Edisi XI, Desember 2018

Kusumaningkuti S. Soetiono dan Cecep Setiawan, 2018, Literasi dan Inklusi Keuangan Indonesia, Depok : Rajawali Press

Mardani, 2015, Aspek Hukum Lembaga Keuangan Syariah Di Indonesia, Jakarta :

Kencana

Muhammad Daud Ali, 2012, Sistem Ekonomi Islam, Jakarta: UI Press

Muhammad Sholahuddin, 2014, Lembaga Keuangan Dan Ekonomi Islam, Yogyakarta : Penerbit Ombak, 2014

Noeng Muhadjir, 1998, Metodologi Penelitian Kualitatif, Yogyakarta : Rake Serasin

Nurul Huda dan Muhammad Haykal, 2010, Lembaga Keuangan Islam, Jakarta : Kencana

Nurul Huda, dkk, 2015, Ekonomi Pembangunan Islam, Jakarta : Kencana

Sukron Kamil, 2016, Ekonomi Islam Kelembagaan dan Konteks Keindonesiaan,(Jakarta : Rajawali Press

Syaifudin Anwar, 1999, Penelitian, Yogyakarta : Pustaka Pelajar

Wawancara, Anggota BMT, tanggal 06 Februari 2020

Wawancara, Ka. Operasional, Shapyani, tanggal 06 Februari 2020

Wawancara, Kepala Kantor Cabang Utama, Dodi Hendra Saputra, tanggal 06 Februari 2020.

Wawancara, Staff Bidang Pengumpulan, Abu Bakar H, tanggal 27 Januari 2020.

Wawancara, Wakil Ketua I Bidang pengumpulan, Abazua Anwar, tanggal 27 Januari 2020.

Zulkifli, 2014, Panduan Praktis Pintar Memahami Zakat, Pekabaru :Suska Press 